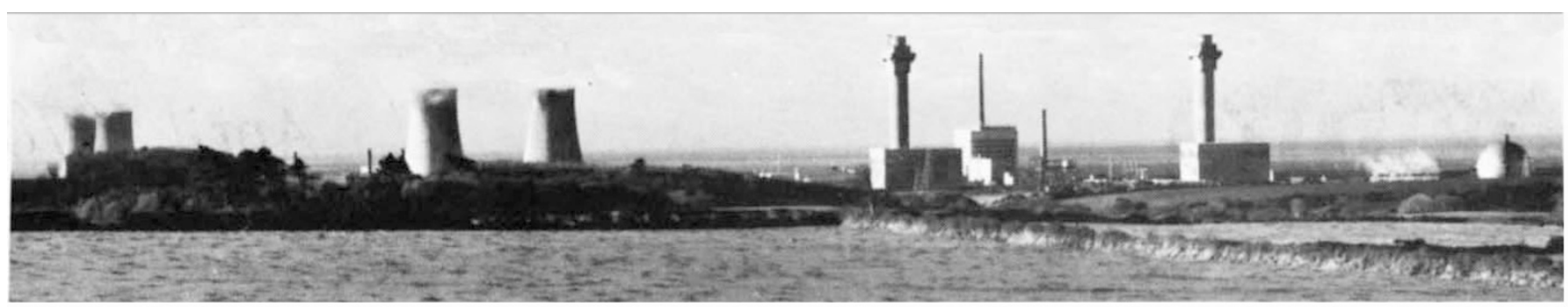

WinIDSCALE may go ahead from 15 May with the design and construction of a 1,200 tonne per year reprocessing facility for oxide nuclear fucl, if the Special Development Order (SDO) laid before the British parliament last week takes effect. The order is subject to "the negative resolution procedure"which is to say it passes undebated unless a member of parliament opposes it. The I iberals have already donc so, and a group of Labour MPs convened by Robin Cook (Edinburgh) are expected to follow suit this week. The result is that there must be a further debatc on Windscale before the 15 May deadline.

"The later the better" said Leo Abse this week. Abse is one of the MPs opposed to the Windscale cxpansion. and he would like as long as possible before the debate "for public opinion to take effect". Friends of the Earth have a demonstration planned for Trafalgar Square on 29 April, and there is some conflict between those who would like the debate before the demonstration and those who would

\section{Windscale to be debated again}

like it after. Abse will see Michael Foot, Leader of the House, this wcek to impress on him that the issue "mustn't have the appearance of being manipulated"-as he clearly believes it has. "They laid the order the day we got back from the Easter recess" he said. "Government are anxious to get the matter through before public opinion builds up".

Frank Hooley, another MP opposed to Windscale, believes that the SDO will be carried whenever the debate takes place. "But I think opinion will move the other waly-if only because of the costs". Effective safeguards. monitoring, and disposal of the waste will ultimatcly be seen to make the plant uneconomic, Hooley believes.
Another factor in the debate will undoubtedly be the Nuclear Non Proliferation Act signed by President Carter last month. The Act threatened to cut off all nuclear fuel supplies to the EEC unless the community agreed to renegotiate the supply treaty with the US. This 20-ycar-old treaty allows Europe to re-export the fuel or its products within its boundaries; so West Germany, for example, would be free to export waste to be reprocessed at Windscale or Cap la Hague in France. The treaty with Japan. on the other hand, allows no movement without US agreement.

The US Scnate sub-Committee on encrgy and non-proliferation wrote to Carter in March expressing disgust at the "mockery" made of US nonproliferation policy by the expansion of reprocessing plants in Europe and it may be now that the open disavowal of US policy expressed by British Foreign Sccretary David Owen in the last Windscale debate (22 March) is beginning to have its effect.

Robert Walgate

than legislation. would seem to be the key. Frankowski's broadcast urged the setting up of a single responsible body to co-ordinate all measures dealing with water conservation. But on what are such decisions to be based? Although a number of development studies have been carried out (partly financed by the UN). notably the plans for the Vistula and Odra basins, the definitive hydrological atlas of Poland. described as a breakthrough work for Polish science is still not ready. This opus, which will present the hydrological relations between the geographical environment and the climate... contain data concerning the water balance. water diffusion from river evaporation. snowfall. the supply of rainfall to water basins. groundwater... ice on rivers and lakes... the water levels in rivers and other water basins, the transport of debris by rivers, the effects of flood levels. and low-water levels in summertime..." would appear to be essential for any comprehensive planning. Yet, according to Dr Juliusz Stachy, head of the production team. data gathering for the atlas has only "just crossed the half-way mark". Dr Stachy is sure that the atlas will be ready by 1980.

Vera Rich
'Outline of the longterm plan of water economy in Poland', which en- in the total demand for water over the period 1970-1990, urgent action. rather 